\title{
AnNA Golonka
}

Uniwersytet Rzeszowski

\section{WYSTEPPE FINANSOWANIA TERRORYZMU (ART. 165A K.K.) W KONTEKŚCIE PROBLEMÓW ZWIĄZANYCH ZE STRONĄ PODMIOTOWĄ TEGO PRZESTĘPSTWA}

\section{WSTĘP}

Proceder finansowania terroryzmu od wielu lat stanowi przedmiot pogłębionych badań naukowych. Poświęcono mu liczne opracowania, przede wszystkim z zakresu kryminologii. Finansowanie terroryzmu, w świetle aktualnego stanu prawnego, jest jednak także pojęciem języka prawnego i zarazem istotą przestępstwa określonego w art. 165a k.k. Warto w tym miejscu przypomnieć, że regulacje dotyczące tego procederu w polskim systemie prawa pojawiły się za sprawą nowelizacji z 27 września 2002 r. do obowiązującej wówczas ustawy z 16 listopada 2000 r. o przeciwdziałaniu wprowadzaniu do obrotu finansowego wartości majątkowych pochodzących z nielegalnych lub nieujawnionych źródeł ${ }^{1}$. Motywem objęcia zakresem tej ustawy również finansowania

Tytuł ustawy zmieniony przez art. 1 pkt 1 ustawy z 25 czerwca 2009 r. o zmianie ustawy o przeciwdziałaniu wprowadzaniu do obrotu finansowego wartości majątkowych pochodzących z nielegalnych lub nieujawnionych źródeł oraz o przeciwdziałaniu finansowaniu terroryzmu oraz o zmianie niektórych innych ustaw (Dz. U. Nr 166, poz. 1317). 
terroryzmu (jako że ze swej natury regulowała ona kwestie związane z przeciwdziałaniem praniu pieniędzy) były niewątpliwie wydarzenia, jakie miały miejsce na arenie międzynarodowej, w tym przede wszystkim zamachy terrorystyczne z 11 września 2001 r. na WTC i Pentagon ${ }^{2}$. Po tej dacie walka $z$ procederem finansowego wspierania ugrupowań terrorystycznych nabrała bowiem nowego znaczenia, a tempo prac legislacyjnych dotyczących zagadnień związanych ze zwalczaniem wszelkich przejawów terroryzmu, zarówno na płaszczyźnie międzynarodowej, jak i krajowej, eskalowało. Wprawdzie jeszcze w okresie poprzedzającym zamachy na WTC zostały opracowane akty międzynarodowe ukierunkowane na kompleksowe zwalczanie terroryzmu (w tym obejmujące międzynarodową Konwencję o zwalczaniu finansowania terroryzmu, przyjętą przez ONZ 9 grudnia 1999 r. ${ }^{3}$ ), jednak po atakach z 11 września problem ten został dostrzeżony przez Unię Europejską, czemu dała ona wyraz na płaszczyźnie legislacyjnej, wytyczając nowy kierunek w zakresie przeciwdziałania temu procederowi ${ }^{4}$.

W przypadku krajów członkowskich Unii Europejskiej regulacje wspólnotowe nadal są podstawowym wyznacznikiem „standardów”, jakie powinny spełniać państwa członkowskie UE, opracowując przepisy

2 Dla porządku wypada przypomnieć, że chodzi tutaj o zamachy 11 września 2001 r. w Nowym Yorku na World Trade Center oraz na Pentagon. Według raportu Komisji powołanej dla zbadania sprawy zamachów w World Trade Center zginęło ponad 2600 osób, 125 osób zginęło w Pentagonie; por. K. LIDEL, Zwalczanie terroryzmu międzynarodowego w polskiej polityce bezpieczeństwa, Warszawa 2010, s. 9-34.

3 Dz. U. z 2004 r. Nr 263, poz. 2620.

4 W tym miejscu można wskazać na takie akty prawa międzynarodowego, jak: Deklaracja (Plan Unii Europejskiej) w sprawie zwalczania terroryzmu (Declaration on Combating Terrorism), przyjęta przez Radę Europejską 25 marca 2004 r. oraz dyrektywy 2005/60/WE Parlamentu Europejskiego i Rady z 26 października 2005 r. w sprawie przeciwdziałania korzystania z systemu finansowego w celu prania pieniędzy oraz finansowania terroryzmu, która została zastąpiona dyrektywą Parlamentu Europejskiego i Rady (UE) 2015/849 z 20 maja 2015 r. w sprawie zapobiegania wykorzystywaniu systemu finansowego do prania pieniędzy lub finansowania terroryzmu - tzw. IV dyrektywa AML/CFT (Dz. Urz. UE L 141/2015, s. 73-117). Na temat regulacji międzynarodowych - por. także M. MATUsiak-FrąCCzak, Przestępstwo finansowania terroryzmu: projekt nowelizacji art. 165a k.k. - analiza prawnoporównawcza, «Przegląd Legislacyjny» 95.1/2016, s. 21-24. 
krajowe. Tym samym stają się one nierzadko jedynym ratio przemawiającym za zmianą dotychczasowych unormowań. Wspomniany motyw legislacyjny stał się wobec tego również powodem nowelizacji ustawy z 16 listopada 2000 r. o przeciwdziałaniu praniu pieniędzy oraz finansowaniu terroryzmu tudzież wprowadzenia do niej definicji legalnej, która pierwotnie odnosiła się do „aktu terrorystycznego” (art. 2 pkt 7). Przepis ten był nie tylko wielce niedoskonały, co zresztą odnotowano w literaturze przedmiotu ${ }^{5}$, ale nadto w ogóle nie przystawał do meritum samej regulacji, która odnosiła się do zapobiegania finansowaniu terroryzmu. Dostrzegając to, nasz ustawodawca nowelizacją z 25 czerwca 2009 r. zmienił ten zapis, zastępując go definicją finansowania terroryzmu, która na gruncie ustawy z 16 listopada 2000 r. oznaczała: „czyn określony w art. 165a k.k.” (art. 2 pkt 10). Dnia 13 lipca 2018 r. weszła zaś w życie ustawa z 1 marca 2018 r. o przeciwdziałaniu praniu pieniędzy oraz finansowaniu terroryzmu, która w art. 2 ust. 1 pkt 6 przewiduje utrzymanie dotychczasowego sposobu definiowania wspomnianego pojęcia.

Odesłanie do art. 165a k.k., zastosowane w art. 2 ust. 1 pkt 6 powołanej ustawy, skłania jednak do bardziej dogłębnej analizy tego pierwszego przepisu, w którym zostało spenalizowane finansowanie terroryzmu. Jest to o tyle zasadne, że przepis ten w ciągu ostatnich kilku lat był już niejednokrotnie nowelizowany. Kolejne jego zmiany, polegające nie tylko na „kosmetycznych” poprawkach jego brzmienia, ale i nadaniu mu znacznie szerszego zakresu, sprawiły, że przepis ten w obecnym kształcie rodzi wiele wątpliwości. Taki stan rzeczy tudzież novum, o jakie pokusił się ustawodawca karny, przewidując możliwość pociągnięcia do odpowiedzialności karnej sprawców, którzy podejmują działania prowadzące do finansowania terroryzmu, pomimo że nie można im przypisać zamiaru popełnienia tego przestępstwa, stanowią asumpt do podjęcia problematyki związanej z regulacją zawartą w art. 165a k.k. Z uwagi na obszerny charakter zagadnienia, w szczególności dotyczący zmian wynikających z wprowadzenia do $\$ 1$ tego artykułu katalogu

Por. np. A. GolonkA, Finansowanie terroryzmu - zagrożenia i sposoby przeciwdziałania. Wnioski 'de lege lata' i postulaty 'de lege ferenda', "Ius et Administratio Facultas Iuridica Universitatis Ressoviensis» 4/2016, s. 6-8. 
przestępstw, których finansowanie - obok przestępstwa o charakterze terrorystycznym - jest obecnie penalizowane ${ }^{6}$, w niniejszym opracowaniu zostaną podniesione przede wszystkim te dylematy, jakie jawią się na gruncie tego przepisu w odniesieniu do strony podmiotowej określonego w nim przestępstwa.

2. Finansowanie terroryzmu W POLSKim KodeKsie Karnym PROBLEMY DOTYCZĄCE UMYŚLNYCH TYPÓW CZYNU ZABRONIONEGO (ART. 165A $₫ 1-3$ K.K.)

Mocą wspomnianej już ustawy z 25 czerwca 2009 r. ${ }^{7}$ polski ustawodawca dokonał nie tylko nowelizacji zapisów przewidzianych w ustawie z 16 listopada 2000 r., lecz także wprowadził do kodeksu karnego nowy typ czynu zabronionego, określony w art. 165a. W świetle pierwotnego brzmienia, jaki nadano art. 165a k.k., za przestępstwo finansowania terroryzmu odpowiadał ten, kto gromadził, przekazywał lub oferował środki płatnicze, instrumenty finansowe, papiery wartościowe, wartości dewizowe, prawa majątkowe lub inne mienie ruchome lub nieruchomości w celu sfinansowania przestępstwa o charakterze terrorystycznym. Przepis ten od początku jego obowiązywania rodził jednak zastrzeżenia wynikające z kierunkowego charakteru tego przestępstwa ${ }^{8}$. Przewidziane w nim wymaganie, by sprawca czynu określonego w art. 165a k.k. podejmował zachowanie „w celu sfinansowania przestępstwa o charakterze terrorystycznym", prowadziło bowiem do wniosku, że z przestępstwem, o którym mowa w art. 165a k.k., mieliśmy do czynienia wówczas, gdy sprawca podejmował wskazaną w tym przepisie czynność sprawczą, tj. gromadził, przekazywał lub oferował środki płatnicze, o których mowa w art. 165a k.k., mając „na celu” popełnienie

6 Zagadnienia te stanowią przedmiot odrębnego opracowania autorki nt. Finansowanie terroryzmu - uwagi na tle znowelizowanego art. 165a k.k. (artykuł na ten temat ukaże się $\mathrm{w}$ «PiP» 74.6-7/2019).

7 Dz. U. Nr 166, poz. 1317.

8 Por. A. Michalska-Warias, New Terrorist Offences in Polish Criminal Law, «Annales Universitas Mariae Curie-Sklodowska», Sectio G, 65.1/2018, s. 104-105. 
przestępstwa, które ze swej istoty wymaga celowego działania ${ }^{9}$. Do takiej konkluzji prowadziła wykładnia omawianego przepisu, uwzględniająca definicję legalną przestępstwa o charakterze terrorystycznym, wskazaną w art. $115 \$ 20$ k.k.

Taki sposób opisu znamion typu czynu zabronionego określonego w art. 165a k.k., zawierający odesłanie do art. $115 \$ 20$ k.k., nie tylko sam przez się komplikował wykładnię normy zawartej w tym pierwszym przepisie $^{10}$, ale nadto także budził, słuszne zresztą, obiekcje, związane z podwójną kierunkowością. Wynikały one przede wszystkim z konieczności każdorazowego wykazania znamienia podmiotowego - „celu” działania sprawcy, którym miało być popełnienie przestępstwa, którego potencjalnym i zarazem „dalszym” celem byłby ten, o którym mowa w art. $115 \$ 20$ k.k., czyli na przykład zmuszenie organu państwowego do podjęcia zachowania pożądanego dla sprawcy, przykładowo wycofania sił zbrojnych z terytorium jakiegoś państwa. Na etapie, na którym nie zostało jeszcze popełnione przestępstwo o charakterze terrorystycznym, „dla potrzeb” popełnienia którego gromadzone są środki finansowe, ustalenie owego „dalszego”, rzeczywistego, celu wydaje się zaś co najmniej trudne, o ile w ogóle możliwe do wykazania ${ }^{11}$.

Ten brak legislacyjny miała za zadanie usunąć zmiana art. 165a k.k., przeprowadzona za sprawą nowelizacji kodeksu karnego z 9 października 2015 r. Jak podnosił legislator w uzasadnieniu do projektu tej ustawy, zmiana dotycząca finansowania terroryzmu została podyktowana rekomendacjami wobec Polski wydanymi przez Moneyval, czyli zespół ekspertów działający przy Radzie Europy, powołany w celu ewaluacji przepisów i środków podejmowanych przez państwa-strony w zakresie

9 Por. K. Wiak, Kryminalizacja finansowania terroryzmu w polskim prawie karnym, «Palestra» 55.7-8/2010, s. 65.

10 W zakresie definicji „finansowania terroryzmu”, na potrzeby stosowania ustawy z 16 listopada 2000 r., konstrukcja ta przewiduje (nadal) „podwójne odesłanie” (uwzględniając treść art. 2 pkt 10 ustawy z 16 listopada 2000 r., czy odpowiednik tego przepisu w ustawie z 1 marca 2018 r., jakim jest art. 2 ust. 1 pkt 6).

${ }^{11}$ Por. A. Golonka, Polskie rozwiązania prawne $w$ zakresie przeciwdziałania finansowaniu terroryzmu, «Prokuratura i Prawo» 3/2013, s. 100-101. O tym także: D. KUCY PER, D. KwiATKOWSKI, Finansowanie terroryzmu na gruncie znowelizowanego art. 165a k.k., «Czasopismo Prawa Karnego i Nauk Penalnych» 3/2018, s. 9-10. 
przeciwdziałania zjawiskom prania brudnych pieniędzy oraz finansowania terroryzmu. Zalecenia te zostały wydane po wizycie ekspertów tego komitetu w Polsce w 2012 r. Jedna z rekomendacji dotyczyła właśnie art. 165a k.k., a jej bezpośrednim powodem było: „[...] pozbawienie przestępstwa finansowania terroryzmu charakteru kierunkowego oraz penalizacja przekazania środków organizacji terrorystycznej lub terroryście w jakimkolwiek celu”. Od 13 lutego 2016 r. przepis ten przybrał więc nowe brzmienie ${ }^{12}$. Analiza przeprowadzonej zmiany prowadzi jednak do wniosku, że deklarowane ratio legis nie zostało w pełni osiągnięte. Uwaga ta - paradoksalnie - odnosi się właśnie do zarzutu podnoszonego w związku z podwójną kierunkowością, jakiej wymagał ustawodawca w pierwotnym brzmieniu art. 165a k.k. Wynika ona z posłużenia się w opisie znamion przestępstwa określonego w art. 165a k.k. dodatkowo (po zmianie dokonanej rzeczoną nowelizacją) określeniem: „[...] albo udostępnienia ich zorganizowanej grupie lub związkowi mającym na celu popełnienie takiego przestępstwa [tj. przestępstwa o charakterze terrorystycznym - A.G.] lub osobie biorącej udział w takiej grupie lub związku"13. W odniesieniu do finansowania terroryzmu podejmowanego przez grupę lub związek przestępczy art. 165a k.k., ustawodawca po wspomnianej zmianie stawiał wymaganie, by sprawca swoim zamiarem obejmował nie tylko podjęcie czynności sprawczej określającej istotę tego przestępstwa, lecz ponadto także, w tym drugim przypadku - gdy przestępstwo o charakterze terrorystycznym miało być popełnione przez grupę lub związek, objęcia nim tego, że celem ich działania będzie popełnienie tego przestępstwa (z rozwinięciem wynikającym z art. 115 $\$ 20$ k.k.). Osobną kwestią było posłużenie się przy tym przez ustawo-

12 Art. 165a k.k. po nowelizacji z 9 października 2015 r. przybrał następujące brzmienie: „Kto gromadzi, przekazuje lub oferuje środki płatnicze, instrumenty finansowe, papiery wartościowe, wartości dewizowe, prawa majątkowe lub inne mienie ruchome lub nieruchomości w zamiarze sfinansowania przestępstwa o charakterze terrorystycznym albo udostępnienia ich zorganizowanej grupie lub związkowi mającym na celu popełnienie takiego przestępstwa lub osobie biorącej udział w takiej grupie lub związku” (Dz. U. poz. 1855).

13 Podobnie: M. Matusiak-Frącczak, Przestępstwo finansowania terroryzmu..., s. 32-33. 
dawcę w opisie znamion tego typu czynu alternatywą rozłączną („albo”) tudzież samo wymaganie, aby podjęcie czynności sprawczej nastąpiło w zamiarze udostępnienia ich osobie, która bierze udział w grupie lub związku, których celem jest popełnienie przestępstwa o charakterze terrorystycznym.

Niedoskonały kształt zapisu przewidzianego w art. 165a k.k., w brzmieniu nadanym mu mocą nowelizacji kodeksu karnego z 9 października 2015 r., jak można by sądzić, dostrzegł sam prawodawca, skoro zdecydował się on na kolejną zmianę omawianego przepisu. Tym samym od 27 kwietnia 2017 r. art. 165a k.k. nadano nowe brzmienie o treści:

„Art. 165a. $\$ 1$. Kto gromadzi, przekazuje lub oferuje środki płatnicze, instrumenty finansowe, papiery wartościowe, wartości dewizowe, prawa majątkowe lub inne mienie ruchome lub nieruchomości w zamiarze sfinansowania przestępstwa o charakterze terrorystycznym lub przestępstwa, o którym mowa w art. 120, art. 121, art. 136, art. 166, art. 167 , art. 171, art. 252, art. 255a lub art. 259a, podlega karze pozbawienia wolności od lat 2 do 12.

$\$ 2$. Tej samej karze podlega, kto udostępnia mienie określone w $\$ 1$ zorganizowanej grupie lub związkowi mającym na celu popełnienie przestępstwa, o którym mowa w tym przepisie, osobie biorącej udział w takiej grupie lub związku lub osobie, która ma zamiar popełnienia takiego przestępstwa.

$\$ 3$. Kto, nie będąc do tego obowiązany na mocy ustawy, pokrywa koszty związane z zaspokojeniem potrzeb lub wykonaniem zobowiązań finansowych grupy, związku lub osoby, o których mowa w $\$ 2$, podlega karze pozbawienia wolności do lat 3.

$\$ 4$. Tej samej karze podlega sprawca czynu określonego w $\$ 1$ lub 2 , który działa nieumyślnie"14.

Zaprezentowany przepis, w jego ujęciu po ostatniej nowelizacji, może jednak rodzić jeszcze więcej obiekcji, związanych nie tylko z jego kształtem i zakresem penalizacji, lecz także stroną podmiotową uregulowanych w nim typów finansowania terroryzmu. W świetle obecnego

14 Ustawa z 23 marca 2017 r. o zmianie ustawy - Kodeks karny oraz niektórych innych ustaw (Dz. U. poz. 768). 
brzmienia umyślne przestępstwo finansowania terroryzmu obejmuje dwa typy zasadnicze (art. 165a \$1-2 k.k.) oraz typ uprzywilejowany (art. $165 \mathrm{a} \S 3 \mathrm{k} . \mathrm{k}$.). Jak wynika $\mathrm{z}$ powołanego przepisu, swoistym novum jest jednak również wprowadzenie do art. 165a paragrafu 4 k.k., przewidującego odpowiedzialność za nieumyślne finansowanie terroryzmu.

Zmiany te, co należy w tym miejscu odnotować, były wynikiem nie tyle dążenia do korekty niedoskonałych zapisów, ile uznania tego za konieczne w świetle zmian regulacji wspólnotowych. Ponadto istotną rolę odegrały także zalecenia komitetu Moneyval wdrażającego rekomendacje FATF, jak również odwołanie się do Konwencji Narodów Zjednoczonych dotyczącej zwalczania prania pieniędzy ${ }^{15}$. Jak bowiem expressis verbis podniesiono $\mathrm{w}$ motywach legislacyjnych rzeczonej zmiany: „Zalecenie generalne sprowadza się do wprowadzenia kryminalizacji zachowań polegających na przekazywaniu środków organizacji terrorystycznej lub terroryście w jakimkolwiek celu. Zalecany zabieg legislacyjny miałby polegać na uzupełnieniu definicji legalnej przestępstwa o charakterze terrorystycznym w sposób gwarantujący objęcie zakresem definiowanego pojęcia wszelkich przestępstw przewidzianych w umowach międzynarodowych wymienionych w Aneksie do ww. Konwencji"16.

Sprostaniu temu oczekiwaniu miała służyć jednak nie zmiana treści art. $115 \$ 20$ k.k., ale wprowadzenie do $\$ 1$ art. 165a k.k. enumeratywnie wskazanych przestępstw, które obok przestępstwa o charakterze terrorystycznym, stanowiącego już element opisu znamion omawianego przestępstwa, uzupełniają obecnie opis finansowania terroryzmu. Część z nowo wprowadzonych, tj. czyny stypizowane w art. 120, 121, 136, 166, 167 i 252 k.k., można by uznać de facto za stanowiące realizację postulatów zasygnalizowanych w uzasadnieniu do projektu nowelizacji. Podniesiono w nim bowiem, że penalizacja finansowania terroryzmu powinna „[...] dotyczyć także przestępstw przewidzianych w umowach

15 Mowa o powołanej wyżej międzynarodowej Konwencji o zwalczaniu finansowania terroryzmu z 9 grudnia 1999 r. (Dz. U. z 2004 r. Nr 263, poz. 2620).

16 Opinia Komisji Kodyfikacyjnej Prawa Karnego przy Ministrze Sprawiedliwości przyjęta po dyskusji plenarnej 18 lutego 2014 r., http://bit.ly/zp19-3-4 (dostęp: 12 maja 2018 r.). 
międzynarodowych wymienionych w Aneksie do ww. Konwencji"17, oczywiście zakładając, że w dotychczasowym kształcie (zważywszy na to, że przestępstwo o charakterze terrorystycznym ma charakter definicji legalnej, a nie odrębnie stypizowanego przestępstwa) postulat ten nie był spełniony. W odniesieniu do pozostałych przestępstw wskazanych w $\$ 1$ art. 165a k.k., w uzasadnieniu do rzekomej potrzeby ich wprowadzenia do tego przepisu podniesiono, że: „[...] finansowanie terroryzmu obejmuje nie tylko przestępstwa, które są stricte terrorystyczne i o charakterze terrorystycznym, [...] ale również za finansowanie terroryzmu uznaje się finansowanie niektórych innych przestępstw, które niekoniecznie mogą być popełniane w celu zastraszenia bądź wywarcia takiego wpływu jak przestępstwo terrorystyczne. Chodzi tutaj o przestępstwa, które zostały wymienione w aneksie do Konwencji Narodów Zjednoczonych o zwalczaniu prania pieniędzy i zwalczaniu terroryzmu. [...] Tak naprawdę ten katalog jest szerszy, bo znajdują się w nim na przykład takie przestępstwa jak zabójstwo, bo chodzi na przykład o zabójstwo dyplomaty, które również uznawane jest za akt terroryzmu, ale w projekcie staraliśmy się ująć tylko te czyny, których natura może być taka, że mogą być po prostu terrorystyczne i stąd właśnie to rozszerzenie" [podkr. - A.G.] ${ }^{18}$. Takie postawienie sprawy, ad meritum, pozwalałoby na znacznie dłuższą analizę zasadności nowelizacji art. 165a k.k., zwłaszcza w kontekście nadanego mu ostatecznie brzmienia, co zresztą przyszło uczynić, poświęcając temu odrębne opracowanie ${ }^{19}$.

W tym natomiast warto skoncentrować się na problematyce dotyczącej strony podmiotowej czynów stypizowanych w art. 165a k.k.

17 Chodzi o Aneks do międzynarodowej Konwencji o zwalczaniu finansowania terroryzmu, przyjętej przez ONZ 9 grudnia 1999 r.

18 Tekst po posiedzeniu Podkomisja nadzwyczajna do rozpatrzenia rządowego projektu ustawy o zmianie ustawy - Kodeks karny oraz niektórych innych ustaw (druk nr 1186) z 21 lutego 2017 r., http://www.sejm.gov.pl/Sejm8.nsf/biuletyny.xsp?viewS (dostęp: 15 lutego 2018 r.).

${ }_{19}$ Zagadnienia te stanowią przedmiot odrębnego opracowania autorki nt. Finansowanie terroryzmu - uwagi na tle znowelizowanego art. 165a k.k. (artykuł na ten temat ukaże się $\mathrm{w}$ «PiP» 74.6-7/2019). 
3. Realizacja postulatu dotycząCEgo usunięcia „PODWÓJNEJ KIERUNKOWOŚCI” W ŚWIETLE ZNOWELIZOWANEGO $\S 1$ ART. 165A K.K.

Jak bumerang powraca w tym miejscu problem, który dostrzegał sam ustawodawca, a którego rozwiązaniu miała służyć wspomniana wyżej nowelizacja art. 165a k.k. ustawą z 9 października 2015 r. Chodzi o kwestię „podwójnej kierunkowości”, jaka od czasu wejścia w życie powołanego przepisu wynikała $\mathrm{z}$ odwołania się $\mathrm{w}$ opisie znamion przestępstwa finansowania terroryzmu do przestępstwa o charakterze terrorystycznym. O trudnościach, jakie powodowało to w związku z koniecznością uzasadnienia strony podmiotowej tego przestępstwa (do zmiany z 9 października 2015 r.), wspomniano już powyżej.

W tym kontekście zatem zabieg legislacyjny polegający na zastąpieniu znamienia „w celu” znamieniem „W zamiarze” okazuje się być prima facie udany. Niestety w praktyce został on jednak (i to do potęgi) zniweczony nowelizacją z 23 marca 2017 r.

W obecnym stanie prawnym bowiem $\mathrm{w}$ art. 165a $\$ 1 \mathrm{k} . \mathrm{k}$. jest wprawdzie nadal mowa o „zamiarze” sprawcy (czyli per se zrezygnowano $\mathrm{z}$ kierunkowego charakteru przestępstwa finansowania terroryzmu), jednak przez odesłanie do przestępstw, z których pewne mają charakter kierunkowy (tj. wymagają wykazania sprawcy zamiaru bezpośredniego o charakterze kierunkowym - dolus directus coloratus), a w dodatku zawierają w opisie znamię odnoszące się do przestępstwa o charakterze terrorystycznym (które - dla przypomnienia - ze swej definicji wymaga działania sprawcy „w celu”), powstaje konstrukcja podmiotowa, do której wyeliminowania dążył ustawodawca, przeprowadzając zmianę art. 165a k.k. nowelą z 9 października 2015 r. To zaś powoduje, że starania podjęte przez ustawodawcę o wprowadzenie korekty omawianego przepisu, które miały ograniczyć trudności w stosowaniu art. 165a k.k., stały się jedynie przyczynkiem do wykładni historycznej tego przepisu. Niestety, wobec braku zmiany systemowej nadal aktualne pozostają problemy, jakie rodzi pozostawienie definicji „przestępstwa o charakterze terrorystycznym”. Godzi się bowiem przypomnieć, słuszne zresztą uwagi, podnoszone na gruncie art. 165a k.k. w brzmieniu sprzed 
nowelizacji z 9 października 2015 r., co do podwójnej kierunkowości, jakiej ustawodawca wymagał od sprawcy finansowania przestępstwa o charakterze terrorystycznym. W bieżącym kształcie art. 165a k.k. nadal jednak powiela on ów „mankament legislacyjny” (najsubtelniej rzecz ujmując), wprowadzając do katalogu przestępstw, których zamierzone finansowanie jest penalizowane, dodatkowo typy czynów określone $\mathrm{w}$ art. 255a $\$ 2$ i art. 259a k.k. ${ }^{20}$ Przestępstwa te mogą zostać popełnione jedynie z zamiarem bezpośrednim (cum dolo directo colorato). Ich prawnokarna natura zakłada, że poza znamionami składającymi się na ich własny opis, powinny one także spełniać znamiona przestępstwa o charakterze terrorystycznym, o którym mowa w art. $115 \$ 20$ k.k. Z racji kilkunastoletniego już funkcjonowania w systemie polskiego prawa karnego tego ostatniego przepisu ${ }^{21}$, jedynie tytułem przypomnienia wypada w tym miejscu przywołać kilka uwag krytycznych, najczęściej zgłaszanych w literaturze przedmiotu pod jego adresem. Podnoszono mianowicie, że powołana definicja ${ }^{22}$ :

- nie uwzględnia w charakterystyce „przestępstwa o charakterze terrorystycznym" w zasadzie żadnego kryterium przedmiotowego i ogranicza się jedynie do znamienia strony podmiotowej, co więcej, czyniąc to przestępstwo kierunkowym;

- istotę omawianego przestępstwa ogranicza (poza powyższym) do wskazania na górną granicę ustawowego zagrożenia karą za dane przestępstwo;

20 Na temat tych przestępstw - por. A. Michalska-Warias, New Terrorist Offences..., s. 105-111.

${ }^{21}$ Paragraf 20 art. 115 został dodany do kodeksu karnego nowelizacją tego kodeksu z 16 kwietnia 2004 r. (Dz. U. Nr 93, poz. 889).

${ }^{22}$ W tej kwestii por. np.: J. MajewsKi, [w:] Kodeks karny. Komentarz. Część ogólna I 2: Komentarz do art. 53-116 k.k., red. W. WróBeL, A. Zoll,Warszawa 2016, «Lex», a także: O. GóRniok, [w:] Kodeks karny. Komentarz², red. O. Górniok, Warszawa 2006, «Lex»; J. GiezeK, [w:] Kodeks karny. Część ogólna. Komentarz, red. J. GiezeK, Warszawa 2012, «Lex»; J. Bojarski, O. Górniok, [w:] Kodeks karny. Komentarz, red. M. Filar, Warszawa 2016, Dokumenty «Lex», dostępne w wersji elektronicznej (komentarze do art. $115 \$ 20$ k.k.). 
- posługuje się znamionami nieostrymi, o ocennym charakterze (takimi, jak np.: „poważne zastraszenie”, „poważne zakłócenia” czy „wiele osób”);

- w zakresie, w jakim odnosi się do groźby popełnienia wskazanego czynu, ma niewłaściwą konstrukcję, utrudniającą jego interpretację (w art. $115 \$ 20$ k.k. ustawodawca wylicza trzy cele działania sprawcy, a dopiero po przecinku dodaje: „[...] a także groźba popełnienia takiego czynu”, co może sugerować, że ta część przepisu ma charakter samodzielny, w tym sensie, iż chodzi w nim o charakter przestępstwa, a bez znaczenia jest to, jaki był rzeczywisty cel działania sprawcy);

- poprzez ogólnie sformułowany cel działania sprawcy może rodzić wątpliwości w przypadku przestępstw kierunkowych (np. przestępstwa rozboju określonego w art. $280 \$ 1$ i 2 k.k., jeżeli doprowadziło ono do zastraszenia wielu osób, które jednak samo w sobie nie było celem działania sprawcy);

- wymaga odmiennego pojmowania groźby od tego, czego wymaga art. $190 \$ 1$ k.k. (groźba karalna określona w art. $190 \$ 1$ k.k. jest popełniona na szkodę osoby, podczas gdy w obliczu powyższej definicji groźba ma odnosić się do popełnienia przestępstwa).

Uwagi te nie tylko nadal zachowują swoją aktualność, lecz także dodatkowo potęguje je kontekst, jakim są inne przestępstwa, na których opis składa się przestępstwo o charakterze terrorystycznym, a których dotyczy przestępstwo finansowania terroryzmu.

W odniesieniu do $\$ 2$ i 3 art. 165a k.k., w zakresie uzasadnienia potrzeby objęcia penalizacją tzw. samotnych wilków, ad meritum, można wyrazić aprobatę dla wprowadzonej zmiany. Zważywszy jednak na przyjęte brzmienie (karalność udostępnienia „mienia”) można postawić pytanie o sam zakres kryminalizacji. Za dalece niefortunne należy uznać posłużenie się w $\$ 2$ art. 165a k.k. znamieniem „mienie, o którym mowa w $\$ 1$ ”, skoro w $\$ 1$ tego przepisu jest mowa o „mieniu ruchomym”. Wykładnia celowościowa nakazuje wprawdzie przyjąć, że w tym przypadku chodzi o wszelkie wartości majątkowe wymienione w $\$ 1$ (a nie tylko verba legis „mienie, o którym mowa w $\$ 1 ”)$, należałoby jednak ponownie zredagować ten przepis, nadając mu poprawne brzmienie. 
Warto również zasygnalizować, że zapis przewidziany w $\$ 2$ art. 165a k.k. jest wybitnie nieprecyzyjny. Niejasne jest także, co oznacza „takie przestępstwo”, o którym mowa w tym przepisie; czy chodzi o przestępstwo polegające na braniu udziału w „takiej grupie lub związku” (ściślej - zorganizowanej grupie lub związku mającym na celu popełnienie przestępstwa wskazanego w $\$ 1$ ), czy przestępstwo, którego celem jest ten, który wynika z charakterystyki przestępstwa o charakterze terrorystycznym. Natomiast w odniesieniu do osoby (karalność udostępnienia „osobie biorącej udział w takiej grupie lub związku lub osobie, która ma zamiar popełnienia takiego przestępstwa”) pojawia się pytanie o to, czy karalne jest udostępnienie osobie, która ma zamiar popełnienia „przestępstwa, o którym mowa w $\$ 1 ”$, czy jednak udostępnienie „mienia” osobie, która ma zamiar popełnienia „takiego przestępstwa”, polegającego na udziale w grupie lub związku, których celem jest popełnienie przestępstwa, o którym mowa w $\$ 1$ art. 165a k.k. Zasygnalizować jednak wypada, że w przypadku, gdy chodziłoby o pierwsze rozwiązanie, sprawca finansowania terroryzmu swoim zamiarem winien obejmować (poza realizacją znamion stanowiących o istocie tego przestępstwa, zgodnie $\mathrm{z} \$ 1$ ) także fakt udostępnienia wartości majątkowych osobie, która ma zamiar popełnienia przestępstwa polegającego na udziale w grupie lub związku przestępczym (tj. przestępstwa określonego w art. 258 k.k.), z tym że ich celem in concreto powinno być jednak nie popełnianie przestępstw w ogóle, ale popełnienie (przynajmniej jednego) przestępstwa, o którym mowa w $\$ 1$ art. 165a k.k. (czyli np. w przypadku przestępstwa o charakterze terrorystycznym takiego przestępstwa, które jest determinowane celem określonym w art. $115 \$ 20$ k.k.) Niewątpliwie $\$ 2$ art. 165a k.k. nie stanowi więc modelowego lex stricta. Pewne wątpliwości budzi także $\$ 3$ art. 165a k.k., z którego wynika, że ustawa może nakładać obowiązek zaspokajania potrzeb lub „wykonywania zobowiązań finansowych” grupy lub związku przestępczego ${ }^{23}$, co gorsze jednak, w tym przypadku chodzi o grupę lub związek, „o których mowa w $\$ 2$ ”, czyli takich, których celem jest popełnienie przestępstwa o charakterze terrorystycznym.

23 Więcej o tym D. Kucyper, D. Kwiatkowski, Finansowanie terroryzmu..., s. $21-23$. 
Wydaje się, że w tym przypadku ratio legis tej zmiany to $\mathrm{w}$ istocie ratio (quod) discessit. Swoją drogą należałoby postawić pytanie o zasadność wprowadzenia tego rozwiązania, a raczej zasugerować uchylenie tego przepisu, skoro w zakresie, w jakim wynika to z odrębnych unormowań, podejmowanie działań na zasadach i w granicach przewidzianych odrębnymi ustawami, w szczególności w zakresie dyktowanym przeprowadzanymi czynnościami operacyjnymi, nie będzie kryminalizowanie i to bez potrzeby odwoływania się do takiego przepisu, jak przewidziany $\mathrm{w} \S 3$ art. 165a k.k.

\section{NIEUMYŚLNE FINANSOWANIE TERRORYZMU, CZYLI TYP CZYNU ZABRONIONEGO OKREŚLONY W ART. 165A $\$ 4$ K.K.}

Powołaną wyżej ustawą nowelizującą z 9 października 2015 r. ustawodawca dodał do art. 165a k.k. paragraf 4, w którym zakresem penalizacji objął również nieumyślne zachowanie sprawcy czynu określonego w $\$$ 1 lub $2^{24}$. Tym samym w obecnym stanie prawnym karalne jest także gromadzenie, przekazywanie lub oferowanie środków płatniczych i innych, wymienionych w tym przepisie wartości majątkowych w sytuacji, gdy sprawca, nie mając wprawdzie zamiaru sfinansowania przestępstwa o charakterze terrorystycznym lub innego przestępstwa, o którym mowa w $\$ 1$ lub 2 art. 165a k.k., popełnia jednak to przestępstwo przez to, że nie dochował ostrożności wymaganej w danych okolicznościach, pomimo iż przewidywał albo mógł przewidzieć, że wskutek tego dojdzie do zrealizowania znamion przestępstwa, o którym mowa w art. 165a $\$ 1$ lub $2 \mathrm{k} . \mathrm{k}$.

Wprowadzenie do kodeksu karnego przestępstwa nieumyślnego finansowania terroryzmu rodzi naturalne pytanie o owe reguły ostrożnego postępowania, jakich ma nie dochować sprawca, mimo że był do tego „zobowiązany” w danym przypadku, jak również o kryteria, według których należałoby przeprowadzić ocenę jego zachowania w tym

24 Ustawa z 23 marca 2017 r. o zmianie ustawy - Kodeks karny oraz niektórych innych ustaw (Dz. U. poz. 768). 
względzie. Może pojawić się bowiem wątpliwość dotycząca tego, czy reguły te są prawnie określone, czy też wystarczy powołanie się na ogólnie, powszechnie przyjmowane normy postępowania, rządzące obrotem gospodarczym ${ }^{25}$. W istocie chodzi więc o ustalenie tego, czy w przypadku przestępstwa finansowania terroryzmu należy odwoływać się do normatywnego wzorca „modelowego obywatela” ${ }^{26}$, czy też, w takim przypadku, należałoby posługiwać się jakimś „podwyższonym” standardem oceny zachowania sprawcy, wyprowadzonym $\mathrm{z}$ modelu profesjonalnego uczestnika obrotu gospodarczego ${ }^{27}$.

Wydaje się, że z uwagi chociażby tylko na opis znamion, w szczególności w zakresie odnoszącym się do podmiotu tego przestępstwa (przestępstwo powszechne) tudzież systematyki kodeksowej, nie sposób byłoby postawić stanowczego wymagania co do konieczności dochowania jakichś szczególnie określonych reguł ostrożnego postępowania przed sprawcą nieumyślnego finansowania terroryzmu, zwłaszcza nie byłoby trafne sięganie po wzorzec „dobrego gospodarza” (skoro nie mamy w tym przypadku do czynienia z przestępstwem, dla którego

25 W doktrynie prawa karnego przyjmuje się, że reguły postępowania z dobrem prawnym, w przypadku braku stosownych regulacji w tym względzie, wyznaczają trzy podstawowe kryteria: kwalifikacje podmiotu, właściwości narzędzi, którymi podmiot się posługuje, sposób wykonywania czynności; por. M. KULIK, A. WĄSEK, [w:] Kodeks karny. Komentarz, red. M. Filar, Warszawa 2016, «Lex», komentarz do art. 9 (teza 10).

26 Zakładając, że modelowy obywatel wyznacza kryteria oceny przewidywania (odpowiednio - możności przewidzenia), o których mowa w art. $9 \$ 2$ k.k. - por. A. ZoLL, [w:] Kodeks karny. Część ogólna, I 1: Komentarz do art. 1-52, red. W. WróBEL, A. ZoLL, Warszawa 2016, «Lex», komentarz do art. 9 (teza 38). Za przyjęciem takiego wzorca opowiada się M. KulıK, [w:] Kodeks karny. Komentarz aktualizowany, red. M. MozGAWA, Warszawa2018, «Lex el.», komentarz do art. 165a k.k. (teza 17).

27 Nawet gdyby przyjąć na potrzeby niniejszego opracowania, że chodziłoby tutaj o wymaganie dochowania takiej staranności, jakiej oczekuje się od każdego, kto prowadzi swoje interesy finansowe w sposób samodzielny - por. A. Rogala, Przestępstwo niegospodarności, Warszawa 1985, s. 58-65, a także J. KocHANowski, Standard „rozsądnego człowieka” w prawie karnym, «Studia Iuridica» 20/1991, s. 125-134, rezygnując z oczywistych powodów z wymagań stawianych przed „dobrym gospodarzem” - w tej kwestii por. np. A. Zientara, Przestępstwo nadużycia zaufania $z$ art. 196 kodeksu karnego, Warszawa 2010, s. 95-97, a także wyrok SN z 5 maja 2004 r., II KK 244/03, «Lex» nr 109482. 
obrót gospodarczy stanowi główne dobro prawnie chronione). Nie wydaje się także poprawne stawianie przed „przeciętnym” obywatelem wymagań dotyczących potrzeby dochowania szczególnych środków bezpieczeństwa finansowego, jakich przestrzegania wymaga ustawa z 1 marca 2018 r. o przeciwdziałaniu praniu pieniędzy oraz finansowaniu terroryzmu. Taka powinność została nałożona mocą znowelizowanych przepisów (podobnie jak to miało miejsce pod rządami ustawy z 16 listopada 2000 r.) jedynie na ,instytucje obowiązane” w rozumieniu art. 2 tej ustawy. Z ustawy tej można wyprowadzić obowiązek takich instytucji do podejmowania środków bezpieczeństwa finansowego (a w przypadkach wskazanych w powołanej ustawie - wzmożonych środków bezpieczeństwa), związanych z oceną poziomu ryzyka prania pieniędzy oraz finansowania terroryzmu. Szczegółowo wskazane obowiązki takich instytucji, wynikające między innymi z art. 27 i 33 tej ustawy ${ }^{28}$, czy z jej art. 50, 74, 86, 89 i 90 (obowiązki związane z identyfikacją oraz zawiadamianiem Generalnego Inspektora Informacji Finansowej o przypadkach uzasadnionego podejrzenia popełnienia przestępstwa określonego w art. 299 k.k. lub w art. 165a k.k.) żadną miarą nie mogą znaleźć zastosowania w odniesieniu do transakcji podejmowanych przez „przeciętnego” obywatela (niebędącego taką instytucją), a wobec tego i oczekiwanie od niego jakiegokolwiek rozważania, czy jej okoliczności

28 Zgodnie z art. 27 ust. 1 ustawy z 1 marca 2018 r. o przeciwdziałaniu praniu pieniędzy oraz finansowaniu terroryzmu (dalej: u.p.p.) instytucje obowiązane identyfikują i oceniają ryzyko związane z praniem pieniędzy i finansowaniem terroryzmu odnoszące się do ich działalności, „z uwzględnieniem czynników ryzyka dotyczących klientów, państw lub obszarów geograficznych, produktów, usług, transakcji lub kanałów ich dostaw”, a działania te winny być „proporcjonalne do charakteru i wielkości instytucji obowiązanej”. Mogą przy tym stosować się do krajowej oceny ryzyka (sporządzanej przez GIIF - art. 27 ust. 2). Natomiast art. 33 ust. 3 u.p.p. przewiduje, że instytucje obowiązane dokumentują rozpoznane ryzyko prania pieniędzy oraz finansowania terroryzmu związane ze stosunkami gospodarczymi lub z transakcją okazjonalną oraz jego ocenę, uwzględniając w szczególności czynniki dotyczące: rodzaju klienta, obszaru geograficznego, przeznaczenia rachunku, rodzaju produktów, usług i sposobów ich dystrybucji, poziomu wartości majątkowych deponowanych przez klienta lub wartości przeprowadzonych transakcji, a także celu, regularności lub czasu trwania stosunków gospodarczych. 
mogą uzasadniać podejrzenia związku z omawianym procederem, jest bezpodstawne. Warto zresztą w tym miejscu zauważyć, że w wypadku, gdyby wiedza na przykład o beneficjencie transakcji była powszechnie znana czy okoliczności transakcji przemawiały za wysokim (a nie jakimkolwiek) prawdopodobieństwem, że stanowi ona realizację znamion przedmiotowych przestępstwa finansowania terroryzmu, to zachowanie sprawcy należy wówczas zakwalifikować jako zamierzone.

Kwestia reguł ostrożności pozostaje w ścisłym związku z formami nieumyślności, jakie penalizuje ustawodawca, a konkretnie chodzi o objęcie zakresem art. 165a $\$ 4$ k.k. tej jego formy, która wiązana jest z nieświadoma nieumyślnością (sprawca nie przewidział, ale mógł, popełnienia przestępstwa wskutek naruszenia reguł ostrożnego postępowania). W tym miejscu należałoby odwołać się do uzasadnienia projektu nowelizacji, z którego można wyczytać, że: „Podejrzenie przestępnego przeznaczenia mienia musi przy tym wynikać z pewnego ciągu informacji, który, przy pomocy zasad logicznego rozumowania, pozwala założyć wykorzystanie mienia w celu wsparcia działalności terrorystycznej. Nie może się natomiast opierać jedynie na domysłach, pogłoskach lub stereotypach" ${ }^{29}$. Z tego wniosek, że ustawodawca zakładał hipotetycznie możliwość (i zasadność) karania jedynie w razie popełnienia nieumyślnie przestępstwa finansowania terroryzmu w formie świadomej nieumyślności. Szkopuł w tym, że nie uznał on za stosowne oddać tego w samym przepisie. Co więcej, dopuszczając możliwość popełnienia przestępstwa zarówno w formie świadomej, jak i nieświadomej nieumyślności, a przy tym wskazując na jego istotę, którą (od strony przedmiotowej) stanowią znamiona opisane w $\$ 1$ i 2 art. 165a k.k., doprowadził do konstrukcji, w której - przykładowo - sprawca teoretycznie nieświadomy (oczywiście w rozumieniu dyktowanym przez pryzmat art. $9 \$ 2$ k.k.) gromadzi, oferuje itp. pieniądze lub inne wartości majątkowe osobie albo grupie lub związkowi, mającym cel wynikający $z$ charakterystyki przestępstwa o charakterze terrorystycznym tudzież innego, na którego opis znamion składa się taki czyn. Wobec braku kry-

29 Druk sejmowy nr 1186 wraz z uzasadnieniem dostępne na stronie: http://www. sejm.gov.pl/sejm8.nsf/druk.xsp?nr=1186 (dostęp: 3 sierpnia 2018 r.). 
teriów pozwalających na wyznaczenie reguł ostrożności wymaganych w danych okolicznościach, przepis $\$ 4$ art. 165a k.k. wydaje się rozwiązaniem nielogicznym, a nawet rodzącym poważne obawy o możliwość jego łatwego „nadużycia” w sytuacji arbitralnie wydawanych rozstrzygnięć. Niestety dalsza analiza podejmowana w tym względzie może prowadzić do jeszcze bardziej absurdalnego wniosku (choć wcale nie niezasadnego w świetle $\$ 4$ art. 165a k.k.), a mianowicie, że sprawca nieumyślnego finansowania terroryzmu nie będzie wprawdzie w sposób zamierzony gromadził, przekazywał lub oferował wartości majątkowych, jednakże dla przypisania mu tego przestępstwa należy wykazać, iż „ciąg informacji” - z uwzględnieniem zasad logicznego rozumowania „pozwala założyć wykorzystanie mienia »w celu« wsparcia działalności terrorystycznej”. Innymi słowy, na podstawie tych informacji sprawca ma przewidzieć albo mieć możność przewidzenia, że czynności te (tj. gromadzenia, oferowania, przekazywania) „posłużą” do popełnienia jakiegoś przestępstwa, zagrożonego karą powyżej pięciu lat pozbawienia wolności i że będzie ono podyktowane celem określonym w art. $115 \$$ 20 k.k. (przestępstwo o charakterze terrorystycznym). Przypomnieć wypada bowiem, raz jeszcze, że typ czynu zabronionego określony w $\$$ 4 art. 165a k.k. wymaga realizacji znamion przedmiotowych opisanych $\mathrm{w} \$ 1$ (odpowiednio - $\mathrm{w} \$ 2$ ) art. 165a k.k. Istotą tego opisu jest natomiast (m.in.) „przestępstwo o charakterze terrorystycznym”, a także inne przestępstwa, z których takie, jak na przykład określone w art. 255a \$2 i art. 259a k.k. w swoim opisie - poza znamieniem celu - zawierają dodatkowo także odesłanie do takiego przestępstwa, które również statuuje przestępstwo kierunkowe. Odesłanie do tych przestępstw, w przypadku przestępstwa nieumyślnego, a takim jest przecież finansowanie terroryzmu, o którym mowa w $\$ 4$ art. 165a k.k., nakazuje postawić duży znak zapytania nad ratio wprowadzenia tego unormowania. O trudnościach wynikających z potrzeby uzasadnienia w praktyce strony podmiotowej sprawcy takiego przestępstwa nie ma potrzeby w tym miejscu nawet pisać. Wreszcie warto podnieść jeszcze jedno, a mianowicie to, że we wskazanym wyżej przypadku (tj. wówczas, gdy z „ciągu informacji, przy pomocy zasad logicznego rozumowania” można wywnioskować, że gromadzone mienie może zostać wykorzystane „W celu wsparcia 
działalności terrorystycznej”) należałoby raczej rozważać przypisanie przestępstwa umyślnego niż nieumyślnego, bowiem tak skonstruowany zapis uzasadnia przekonanie, że sprawca przynajmniej godził się na taki stan rzeczy.

Nie mniej problematyczne może okazać się również samo uzasadnienie dotyczące strony podmiotowej nieumyślnego finansowania terroryzmu, co odnosi się do konieczności ustalenia, kiedy sprawca finansowania terroryzmu będzie podejmował zachowanie z zamiarem wynikowym, a kiedy w formie świadomej nieumyślności.

$\mathrm{W}$ tym względzie, $\mathrm{z}$ dogmatycznego punktu widzenia, sprawa wydaje się nie budzić większych (niż normalnie) trudności wynikających z potrzeby ustalenia tego, czy sprawca, przewidując możliwość popełnienia czynu zabronionego, na to się godził, a więc czy popełnił on czyn umyślnie z zamiarem ewentualnym czy też bezpodstawnie sądził, że uniknie realizacji znamion typu czynu zabronionego (świadoma nieumyślność). Doktryna prawa karnego przychodzi z pomocą w tej kwestii. Prezentuje ona różne rozwiązania, $z$ których (w tym miejscu) na uwagę może zasługiwać koncepcja prawdopodobieństwa (niem. Wahrscheinlichkeitstheorie), pozwalająca na wskazanie, gdzie przebiega "granica” między dwoma wspomnianymi. W jej ujęciu stopień uświadomionego prawdopodobieństwa tego, że dojdzie do realizacji znamion typu czynu zabronionego, „wytycza” tę granicę. Jeżeli bowiem stopień ten (co do zasady) jest wyższy od „przeciętnego", to powinno to zarazem przemawiać za wystąpieniem elementu godzenia się, a zatem i za przyjęciem umyślności (w postaci zamiaru ewentualnego). A contrario - jeżeli zaś stopień ten jest niższy od „przeciętnego", to uzasadnione będzie przyjęcie świadomej nieumyślności ${ }^{30}$. Innymi słowy, jak to swego czasu ujmowano w literaturze przedmiotu, stopień powinności, która jako kategoria psychologiczno-prawna oznacza rodzaj subiektywnego, indywidualnego przeżycia, paralelnego do możliwości, mającej charakter imperatywu, podlega gradacji. Jej stopień można zaś wyrazić stosunkiem przedsięwziętych środków ostrożności do prawdopodobieństwa niebezpieczeń-

30 Por. np. J. Lachowski, [w:] Kodeks karny. Komentarz, red. V. Konarska-Wrzosek, Warszawa 2016, «Lex», komentarz do art. 9 (teza 15). 
stwa $^{31}$. Takie podejście uzasadnia stwierdzenie, że wynik tego stosunku mniejszy od przeciętnego (oznaczony jako małe prawdopodobieństwo) może uzasadniać odpowiedzialność za przestępstwo nieumyślne, jeśli zaś prawdopodobieństwo niebezpieczeństwa jest znaczne (wyższe niż przedsięwzięte środki ostrożności), to stanowi podstawę uznania, że zachodzi „zarzucalny, relewantny niedobór powinnościowy”32. Słusznie jednak podnoszono zarówno w teorii, jak i w praktyce prawa karnego, że taki sposób „wytyczania granicy” pomiędzy zamiarem ewentualnym a świadomą nieumyślną jest nie tylko, że mało wymierny, ale przede wszystkim z praktycznego punktu widzenia nierzadko bardzo trudny do przeprowadzenia $^{33}$. Z kolei odnosząc to do omawianego tutaj zagadnienia, wypada dostrzec, że wobec braku kryteriów wyznaczających reguły postępowania, jakich dochowania należałoby oczekiwać od przeciętnego obywatela podejmującego czynności w obrocie finansowym, stopień przewidywania będzie nie tylko niższy od przeciętnego, ale nierzadko zasadne może się okazać przyjęcie, że będzie on w ogóle za niski do przypisania przestępstwa nieumyślnego ${ }^{34}$. Na taką zresztą konkluzję roztropnych organów stosujących prawo, w myśl sentencji: scire leges non hoc est verba earum tenere, sed vim ac potestatem ${ }^{35}$, należy liczyć w praktyce wobec, jak się zdaje, niedostatecznie przemyślanego sensu wprowadzenia tej regulacji do kodeksu karnego.

31 W. Świtka, Psychologiczna analiza winy $w$ polskim prawie karnym (studium psychologiczno-kryminalne, Rzeszów 1977, s. 67-69.

32 Ibidem, s. 69.

33 Por. H. PopŁAwski, Zamiar ewentualny a potrzeby praktyki sadowej, «Palestra» 6.3-4/1962, s. 82; por. także T. KACZMAREK, Sporne problemy umyślności, [w:] Umyślność i jej formy. Pokłosie VII Bielańskiego Kolokwium Karnistycznego, red. J. MaJEwsKI, Toruń 2011, s. 41-43.

34 Trafnie podkreślono w doktrynie prawa karnego, że: „Nie wolno poprzestać na bliżej niesprecyzowanym obowiązku ostrożnego działania”, gdy stawia się sprawcy zarzut popełnienia czynu nieumyślnego albo przypisuje mu się taki czyn; por. J. LACHOWsкi, [w:] Kodeks karny. Komentarz, red. V. Konarska-Wrzosek, komentarz do art. 9 (teza 13).

35 Scire leges non hoc est verba earum tenere, sed vim ac potestatem (łac.) - znać ustawę to nie trzymać się jej słów, lecz rozumieć jej (sens i) znaczenie. 


\section{Podsumowanie}

Na podstawie zaprezentowanych wyżej uwag dotyczących kolejnych nowelizacji art. 165a k.k. nasuwa się podstawowy wniosek, że wszystkie z nich zostały podyktowane wyłącznie zmianami regulacji wspólnotowych, w konsekwencji czego, przepis ten na przestrzeni stosunkowo niedługiego okresu jego obowiązywania był już niejednokrotnie nowelizowany. Taki stan rzeczy sam w sobie nie jest zjawiskiem pożądanym, chociażby tylko z perspektywy zapewnienia stabilności prawa. W omawianym przypadku jednak kolejne nowelizacje nie tylko nie doprowadziły do poprawy brzmienia art. 165a k.k., ale wręcz przyczyniły się one do wypaczenia sensu tego przepisu. Najbardziej dobitnym tego przykładem są wszelkie wątpliwości, jakie jawią się na gruncie art. 165a k.k. i odnoszą się do strony podmiotowej opisanych tam typów czynów zabronionych. Jak wynika z zaprezentowanej analizy, niemało zastrzeżeń może budzić kwestia dotycząca podwójnej kierunkowości, do której wyeliminowania dążył legislator, decydując się na zmianę art. 165a k.k. nowelą z 9 października 2015 r., a którą zmultiplikował przez uwzględnienie w katalogu przestępstw objętych penalizacją na podstawie $\$ 1$ art. 165a k.k. tych, które w swoim opisie zawierają znamię odnoszące się do przestępstwa o charakterze terrorystycznym. To zaś wymaga podjęcia działania determinowanego celem wskazanym w art. $115 \$ 20$ k.k. Jeszcze więcej zastrzeżeń może budzić wprowadzenie do kodeksu karnego przepisu przewidującego karalność nieumyślnego finansowania terroryzmu, które poza tym, że niejako ex definitione zdaje się zawierać w sobie pewną niedorzeczność (zwłaszcza wobec potrzeby odwołania się do definicji przestępstwa o charakterze terrorystycznym), to nadto także może zastanawiać w kontekście uzasadnienia wprowadzonej zmiany. Nasuwa ono uwagi co do rzeczywistego ratio przemawiającego za koniecznością zmiany art. 165a k.k., a i może prowadzić do konkluzji, że nawet sam legislator stracił je z pola widzenia, decydując się na ostateczne brzmienie tego przepisu. 
WYSTĘPEK FINANSOWANIA TERRORYZMU (ART. 165A K.K.) W KONTEKŚCIE PROBLEMÓW ZWIĄZANYCH ZE STRONĄ PODMIOTOWĄ TEGO PRZESTĘPSTWA

\section{Streszczenie}

Przedmiotem opracowania są zagadnienia związane z przestępstwem finansowania terroryzmu określonym w art. 165a k.k. Przepis ten w ciągu ostatnich dwóch lat był już dwukrotnie nowelizowany. Druga z nich, przeprowadzona ustawą z dnia 23marca 2017 r., przewidziała daleko idącą modyfikację typów czynów zabronionych uregulowanych w art. 165a k.k., w tym ustanawiając karalność nieumyślnego finansowania terroryzmu. Nowe brzmienie, jakie przybrał ten przepis zostało podyktowane zmianami w regulacjach wspólnotowych, a także wskazaniami Komitetu Moneyval, które legły u podstaw uzasadnienia niekoniecznie zasadnej nowelizacji. Co więcej, za jej sprawą w przepisie tym znalazł się niejeden zapis, który budzi poważne zastrzeżenia, zwłaszcza z perspektywy ratio legis zmian, tudzież zgodności z zasada określoności. Niedoskonały kształt tego przepisu budzi jednocześnie wątpliwości związane z możliwością jego praktycznego stosowania, a w konsekwencji również samą efektywnością zwalczania finansowania terroryzmu. Odnosi się to przede wszystkim do aspektów dotyczących strony podmiotowej typów czynów zabronionych opisanych w art. 165a k.k. Problematyka ta znajduje rozwinięcie w przedmiotowym artykule naukowym.

The Offence of Financing Terrorism (Article 165a of the

Polish Criminal Code) in the Context of Problems Related to the Subjective Aspects ('Mens ReA') of this Crime

\section{Summary}

The subject of this study are issues related to the crime of financing of terrorism specified in Article 165a of the Polish Criminal Code. This provision has been amended twice in the last two years. The second amendment, under the Act of 23 March 2017, provided for a far-reaching 
modification of the types of prohibited acts regulated in Article 165a of the Polish Criminal Code, including the penalisation of unintentional financing of terrorism. The new wording adopted by this provision was dictated by changes in European Union regulations, as well as in the Recommendations of the Moneyval Committee underlying the justification for an otherwise not very well-grounded amendment. Moreover, this amendment has introduced several changes that raise serious reservations, especially from the perspective of ratio legis, as well as compliance with the principle of specificity. The defective form of this provision also raises doubts regarding the possibility of its practical application and consequently the effectiveness of combating terrorist financing. This applies above all to the aspects related to the subjective side of the types of prohibited acts described in Article 165a of the Polish Criminal Code. This issue is discussed at length in the present article.

Słowa kluczowe: finansowanie terroryzmu; strona podmiotowa; przestępstwo nieumyślne; przestępstwo o charakterze terrorystycznym.

Keywords: financing terrorism; mens rea, unintentional offence; a terrorist offence.

\section{Literatura}

Bojarski J., Górniok O., [w:] Kodeks karny. Komentarz, red. M. Filar, Warszawa 2016. Dokumenty «Lex», dostępne w wersji elektronicznej (komentarz do art. $115 \$ 20$ k.k.).

Golonka A., Finansowanie terroryzmu - zagrożenia i sposoby przeciwdziałania. Wnioski 'de lege lata' i postulaty 'de lege ferenda, «Ius et AdministratioFacultas Iuridica Universitatis Ressoviensis» 4/2016, s. 6-8.

Golonka A., Polskie rozwiązania prawne w zakresie przeciwdziałania finansowaniu terroryzmu, «Prokuratura i Prawo» 3/2013, s. 100-101.

Górniok O., [w:] Kodeks karny. Komentarz², red. O. GóRniok, Warszawa 2006. GiezeK J., [w:] Kodeks karny. Część ogólna. Komentarz, red. J. GiezeK, Warszawa 2012.

Kaczmarek T., Sporne problemy umyślności, [w:] Umyślność i jej formy. Pokłosie VII Bielańskiego Kolokwium Karnistycznego, red. J. MaJEwski, Toruń 2011, s. 41-43. 
Kochanowski J., Standard „rozsądnego człowieka” w prawie karnym, «Studia Iuridica» 20/1991, s. 125-134.

Kucyper D., Kwiatkowski D., Finansowanie terroryzmu na gruncie znowelizowanego art. 165a k.k., "Czasopismo Prawa Karnego i Nauk Penalnych» 3/2018, s. 9-10.

Kulik M., WąSEK A., [w:] Kodeks karny. Komentarz, red. M. Filar, Warszawa 2016, «Lex», komentarz do art. 9.

Kulik M., [w:] Kodeks karny. Komentarz aktualizowany, red. M. Mozgawa, Warszawa 2018, «Lex el.», komentarz do art. 165a k.k.

Lachowski J., [w:] Kodeks karny. Komentarz, red. V. Konarska-WrzoseK, Warszawa 2016, «Lex», komentarz do art. 9.

LIDEL K., Zwalczanie terroryzmu międzynarodowego w polskiej polityce bezpieczeństwa, Warszawa 2010, s. 9-34.

Majewski J., [w:] Kodeks karny. Komentarz. Część ogólna 5 , I 2: Komentarz do art. 53-116 k.k., red. W. WróBel, A. ZolL, Warszawa 2016, «Lex».

Matusiak-FrącCZak M., Przestępstwo finansowania terroryzmu: projekt nowelizacji art. 165a k.k. - analiza prawnoporównawcza, «Przegląd Legislacyjny» 95.1/2016, s. 21-24.

Michalska-Warias A., New Terrorist Offences in Polish Criminal Law, «Annales Universitas Mariae Curie-Sklodowska, Sectio G, 65.1/2018, s. 104-111.

PopŁAWski H., Zamiar ewentualny a potrzeby praktyki sadowej, «Palestra» 6.3-4/1962, s. 82.

Świtka W., Psychologiczna analiza winy $w$ polskim prawie karnym (studium psychologiczno-kryminalne), Rzeszów 1977, s. 67-69.

WiAK K., Kryminalizacja finansowania terroryzmu w polskim prawie karnym, «Palestra» 55.7-8/2010, s. 57-65.

Zientara A., Przestępstwo nadużycia zaufania z art. 196 kodeksu karnego, Warszawa 2010, s. 95-97.

Zoll A., [w:] Kodeks karny. Część ogólna, I 1: Komentarz do art. 1-52, red. W. WróBel, A. Zoll, Warszawa 2016, «Lex», komentarz do art. 9. 